\title{
Britain as Sjónbverfing: Decoding the Landscape in Strengleikar
}

\author{
Erin Michelle Goeres
}

University College London

\begin{abstract}
7 eitarlauf is an Old Norse translation of Marie de France's lai du Chievrefoil. Only II 8 lines long in the original, and covering just under one manuscript page in the Norse, the lai describes a single episode in the long and complicated story of Tristan and Isolde. Banished from the court of King Mark, Tristan hears that the queen plans to ride to Tintagel for Pentecost. He hides in the forest along the route and carves a message on a hazel branch. In the Anglo-Norman text, the exact nature of this message is unclear, ${ }^{1}$ but the Old Norse version quotes it in full:
\end{abstract}

Sva fer $r$ með ocr kvað hann sem viðuindil sa er bin $n z$ um hæslivið. Meðan pessir tveir viðir bua baðer saman. pa liva ok bera lauf sitt. En sa er pessa viðe skildi hvarn frá oðrum. pa déyr haslen $n$ ok pui nest uiðvin $n$ dille $n$ n ok ber $r$ hvarki lauf. nema porna ok firir verðaz bæðe. Hin friða u $n$ nasta min. Sva ok eftir pei $m$ hætti ero vit. Ei ma ec lifa on pin. ok ei pu on min. (Cook and Tveitane 1979, 198) ${ }^{2}$

"It goes with us," he said, "as with the honeysuckle that fastens itself around the hazel tree. As long as these two trees are together they live

I. Jean Rychner gives a summary of the various readings in his edition (I983, 276-80); for a more detailed discussion, see Friederike Wiesmann-Wiedemann (I978). Chievrefoil is preserved in two manuscripts, British Library, Harley 978 and Bibliothèque Nationale, Nouvelles acquisitions françaises IIO4. The manuscript context of the lai will be discussed in more detail below.

2. All citations of Strengleikar are from the edition by Cook and Tveitane (I979). 
and produce foliage, but if anyone should separate these trees from each other, the hazel will die and then the honeysuckle, and neither of them will produce foliage; instead, they will both dry up and perish. My beautiful sweetheart, such and in the same way are we. I cannot live without you, nor you without me." (Cook and Tveitane I979, I99)

The hazel branch functions as both message and metaphor in a telescopic layering of interpretative meaning. Isolde must find, read, and decode the message inscribed upon it; the message then invites her to compare the physical object she holds to the emotional and sexual ties that bind her to Tristan. ${ }^{3}$ As Peter Haidu writes: "The stick is a natural sign of itself. The sign, which normally supposes the absence of the signified, here signifies its presence" (2004, I30). The very wood through which Isolde rides becomes a symbol of secret communication and illicit desire. Isolde successfully interprets both message and metaphor, and the resulting meeting between the lovers gives rise to a new text, the lai itself. Geitarlauf demonstrates well the symbolic relationship between the act of traveling through the natural world and that of interpreting the written text. Indeed, this relationship is developed throughout the whole of Strengleikar, the compilation of translated Breton lais in which Geitarlauf is found. In particular, the island of Britain emerges as a key site for such explorations. It will be argued here that the Strengleikar collection demonstrates a sustained interest in the role of Britain as a setting for the romance text, and that travel through the British landscape parallels the process of reading and decoding the romance genre itself.

Consisting of twenty-one prose tales, Strengleikar translates into Old Norse eleven of the lais attributed to Marie de France, as well as six anonymous French poems; a further four of the Old Norse texts have no known origin. The collection is largely preserved within one manuscript, Uppsala University Library, de la Gardie 4-7. ${ }^{4}$ The manuscript dates to around the year 1270 and was likely produced in Bergen or the surrounding area. The translation was reputedly commissioned by

3. This episode may also reference the end of the Tristan legend: although the lovers are buried on opposite sides of a church, two trees sprout from their graves and meet in the air above. As the Old Norse Tristrams saga notes, "Ok má pví sjá, hversu mikil ást peira á milli verit hefir" (Jorgensen I999, 222) [And by this we can see how great the love between them had been (223)].

4. A detailed description of the manuscript context is available in the introduction to the facsimile edition (Tveitane I972). 
Hákon Hákonarson, king of Norway, as part of a campaign to import Continental romance texts to his country. Ruling from I2I7 to I263, Hákon developed a keen interest in the life of the Anglo-Norman court and seems to have commissioned the translation of the lais as part of a wider cultural program that included the translation of several romance texts into Norse, as well as the adoption in Norway of English styles of painting, sculpture, and architecture. Such forms of cultural exchange were supported by a mutual reliance on trade and an increasingly close relationship between political and ecclesiastical authorities (Leach I92I; Helle I968; Kalinke 20II). Recent studies have emphasized the processes of cultural and ideological translation that took place under Hákon as Norway, and indeed the rest of Scandinavia, began to embrace the courtly texts and customs of southern Europe (Sif Rikhardsdottir 20I2; Kalinke 20II; Eriksen 2007). As Carolyne Larrington observes:

Hákon's aim of centralizing political power in Norway, transforming old warrior-based, regional and autonomous power bases into a medieval European feudal state whose ideological center was the royal court, was underpinned by the promotion of European Arthurian literature in which a powerful king adjudicated honor and status in a worldfamous court. $(2009,506)$

As will be seen below, Strengleikar is a collection that promotes both the political and the cultural agenda of its royal patron.

The Old Norse translator is not named in the text but is often identified with the "Bróðir Robert" named in the prologue to Tristrams saga ok Isöndar; he also appears as "Roðbert aboti" in the epilogue to Elis saga, a translated chanson de geste. It has been suggested that this "Brother Robert" was an Anglo-Norman cleric working at the court of King Hákon (Schach 1975, II7-35), although he may have been only one of several translators to work on the Strengleikar compilation (Cook and Tveitane I979, xxii-xxviii). The voice of this translator or group of translators emerges clearly in the prologue to the collection, presenting the work as a didactic text that supports the king in his project of national self-improvement:

$\langle A\rangle T$ hæve pæirra er i fyrnskun ni varo likaðe oss at forvitna ok rannzaka pui at pæir varo listugir i velom sino $m$ glogsyn $i r$ i skynsemdo $m$. hygnir i raðagærðom vask $i r$ i vapno $m$ høeversk $i r$ hirðsiðum millder i giofu $m$ ok $\langle a t\rangle$ allz/skonar drængscap. hinir frægiazto . . . huerfr pess giorsamlegre sem hæims pæssa dagar mæirr fram liða. (Cook and Tveitane I979, 4) 
It pleased us to inquire about and examine the deeds of those who lived in olden days, because they were skilled in their arts, discerning in their reason, clever in their counsels, valiant with weapons, well-mannered in the customs of the court, generous with gifts, and most famous for every kind of nobility. ... [T] [Tese things are disappearing more and more as the days of this world march on. (Cook and Tveitane 1979, 5)

Ad Putter has shown in his extensive study of Sir Gawain and the Green Knight that Arthurian romance offered an important means through which the violence of the king's warriors could be refashioned into more peaceful, courtly behaviors (I995; cf. also Jaeger I985). One of the earliest scholars to examine Strengleikar, Rudolf Meissner (I9O2) suggested a similar function on the part of the Old Norse lais, and the role of the translated romances and lais in the promotion of courtly and chivalric ideology is now widely accepted. ${ }^{5}$ The Strengleikar prologue explicitly advertises the educative potential of courtly genres such as the Breton lai and, moreover, praises King Hákon for his role in effecting the translation of such texts from France to Norway:

$\langle\mathrm{E}\rangle_{\mathrm{N}}$ bok pessor er hin $n$ virðulege hacon konongr let norrána or volsko male ma hæita lioða bok. pui at af pæim sogum er pæssir bok birtir gærðo skolld i syðra brætlande er liggr i fran $n z$ lioðsonga. (Cook and Tveitane 1979,4 )

This book, which the esteemed King Hákon had translated into Norse from the French language, may be called "Book of Lais," because from the stories which this book makes known, poets in Brittany-which is in France-composed lais. (Cook and Tveitane 1979, 5)

It has been argued that the line between Breton and Briton is blurred in the lais of Marie de France, and that geographical difference is secondary to the shared experience of Norman colonization (Haidu 2004, I39; see also Warren 2000). However, as the citation above demonstrates, the Old Norse prologue clearly emphasizes the Continental origins of the text and the act of translation that has brought it to Norway. It is no surprise, therefore, that movement emerges as a key theme in the collection, which exemplifies the process of translatio in its widest possible sense. Just as the movement of the lais participates in the promotion of courtly behaviors, so, too, does travel allow the protagonists of Strengleikar to explore the literary ideals of romance 
and chivalry. The translation of the lais to the court of King Hákon promotes a process of intellectual exploration on the part of the audience that is explicitly framed in terms of travel; indeed, it has much in common with the rhetorical practice of ductus, the way in which a work of art leads the reader or viewer through itself, as though on a mental journey (Carruthers 20IO, I90). Mary Carruthers's exploration of ductus in early medieval monastic writings emphasizes the way in which "one 'sees' one's reading, and one 'walks' through it, not just to store it away conveniently and safely, in order to be able to be able to reconstruct it as it was, but also in order to meditate on it, digest it, interpret it. ... A reader is constantly in motion" (I998, IIO). Strengleikar offers a secular analogue to Carruthers's example texts in the mental journey that it demands of, and promotes in, its audience.

Although the Breton provenance of these stories is repeatedly emphasized, seven of the lais take place in the Celtic regions of Britain, while two are explicitly linked to the Arthurian legends of those regions. It has been observed that the literary understanding of Arthurian geography tends to divide along linguistic and cultural lines: French texts tend to keep the geography of the Arthurian world vague, locating Arthur's court at the undefined location of Camelot, while many of the anonymous English sources focus on sites of real political importance, frequently locating the king's court at Carlisle (Rouse and Rushton 2009). It is not my intent here to make generalizations of this sort for the whole of the Scandinavian corpus, but it is possible to discern a comparable pattern in the Strengleikar collection. That is, Strengleikar portrays the British landscape in two apparently contradictory ways. On one hand, the Old Norse descriptions of the island of Britain are remarkably detailed when compared to the French source texts; the Old Norse translator adds a number of details that help to situate Britain in relation to the Continent. On the other hand, descriptions of the British landscape itself are extremely vague; Britain is often cloaked in a dreamlike and even hallucinatory atmosphere. Seen from a distance, Britain is fixed in the geography of Northern Europe; seen from within, it is a land of deception and confusion. This tension between clarity and obscurity is one that the protagonists of Strengleikar must learn to negotiate as they travel through the landscape. The learning process that this produces is analogous to that of Strengleikar's audience at the court of King Hákon: the Norwegian court is also led on a journey as they learn to find their way through the newly imported world of Arthurian romance and its associated texts. 


\section{DOUN}

Of the twenty-one lais in Strengleikar, seven are set in whole or in part in Britain: Geitarlauf, Janual, Jonet, Milun, Gurun, Doun, and Desire. The first four of these are translated from the lais of Marie, now preserved most fully in a manuscript dating from the mid-thirteenth century, London, BL Harley 978. ${ }^{6}$ Although the lai of Gurun is thought to date from nearly a century earlier (Rychner I983, viii-xlv), it has no known source, whereas the sources of Doun and Desire can be found in an anonymous French collection dating to the end of the thirteenth century; this manuscript also records a number of Marie's lais and is now held in Paris at the Bibliothèque Nationale, Nouvelles acquisitions françaises IIO4 (Cook and Tveitane I979, xvi-xviii). ${ }^{7}$ It is only possible here to discuss two examples of the geographical theme discussed above, although it is a feature of the majority of the Strengleikar texts set in Britain. The focus here will be on the anonymous lais Doun and Desire, whose inclusion in the Strengleikar manuscript sets them in conversation with their more famous counterparts, those attributed to Marie. Unlike lais such as Geitarlauf and Janual, which are linked explicitly to the Arthurian world of Wales and Cornwall, these two lais are set in Scotland. Both describe the adventures of young male heroes and their relationships with powerful women who have a strong hint of the supernatural about them. ${ }^{8}$

In its portrayal of Britain, Doun exemplifies the tension between clarity and obscurity noted above. ${ }^{9}$ The lai opens with a description of a haughty woman who rules over part of Scotland. As a woman who rules in her own right, she has much in common with the "maiden kings" of the Icelandic riddarasögur (cf. Kalinke 1990, 66-IO8; Sif

6. For a full discussion of the extant manuscripts, see Rychner (1983, xix-xxviii). Although the texts are only recorded in manuscripts dating from the mid-thirteenth century and later, the lais are generally thought to have been composed during the latter half of the twelfth century.

7. Desire is also found in Cologny, Bibliotheca Bodmeriana, MS Bodmer 82; this manuscript dates to the thirteenth century. Both texts are likely Anglo-Norman in origin and may have been composed in Britain (Burgess and Brook 2007, II-2, 245).

8. There are, however, possible Arthurian undertones to both tales. The Scottish location led R. S. Loomis to suggest a connection between the women in these lais and Morgan le Fay (I949, IO8-I4); Jean-Claude Lozac'hmeur has argued that the name Desiré derives from a corruption of the epithet "desiré" and that the lai represents a lost tale about the Arthurian knight Yvain (1984).

9. For a discussion of the principal themes and characters of the Anglo-Norman lai de Doon, as well as its analogues in the Lais of Marie de France, see Burgess and Brook $(2007,245-73)$. All citations are from this edition. 
Rikhardsdottir 2OI2, II3-5I), while her uncanny beauty and quasimagical abilities also link her to the enchantresses of Arthurian romance (cf. Larrington 2008). As the French text says:

Ce m'est avis, se droit recort, Les Daneborc, qui est au nort, Manoit jadis une pucele A merveille cortoise e bele. Le païs ot en heritage, N'i orent autre seignorage, Et a Daneborc conversoit; Ce ert le leu que molt amoit. Por li e por ses damoiseles Fu dit le Chastel as Puceles. La pucele dont je vos di Por sa richesce s'orgueilli; Toz desdaignoit ceus du païs. (Burgess and Brook 2007, vv. 7-I9)

It seems to me, if I recall aright, / That near Edinburgh, which is in the north, / There once lived a maiden, / Exceedingly courtly and beautiful. / She held the land as her inheritance, / There was no other lordship, / And she dwelt in Edinburgh; / She loved this place very much. / Because of her and her damsels / It was called the Castle of Maidens. / The maiden I am telling you about / Became proud on account of her wealth; / She scorned all the men in the land. (Burgess and Brook 2007, 26I)

The woman declares that she will only marry the man who can ride in one day from Southampton to Edinburgh. This all seems relatively straightforward, yet the Norse translation elaborates substantially on the geographical description of this challenge. There is no mention of the mysteriously alluring Chastel as Puceles; rather, the Old Norse translator prosaically locates his lai "norðr a skottlande par sem heitir edenburg" (Cook and Tveitane I979, I5O) ["up north in Scotland, at the place called Edinburgh" (I5I)]. He also elaborates on the nature of the challenge:

hon kvazc engan mann vilia hafa nema $\operatorname{pan} n$ er sva mikit gere sacar astar hen nar. at hann riði á einvm degi or suðantun er sten $n d r$ a svnnanverðo englan $n$ de. ok norðr til edine borgar par sem hon sat á skotlan $n$ de. (Cook and Tveitane I979, I5O)

She said that she would have no man but one who would do so much out of love for her as to ride in one day from Southampton, which is in the south of England, north to Edinburgh, which is where she lived in Scotland. (Cook and Tveitane I979, I5I) 
The addition of cardinal directions here intensifies the challenge: would-be suitors must ride from the very south of the island all the way north to Edinburgh. It also helps the Norse audience of the lai to construct a far more precise mental map of the landscape in question. We see this also in the Old Norse description of the lady's fame: in French, "Loing fu portee la novele / De l'orgueilleuse damoisele" (Burgess and Brook 2007, vv. 65-6) ["The news was carried far and wide / About the proud maiden" (Burgess and Brook 2007, 263)]. In the Norse, however, "pessi tiðen $n$ de varo viða fregin um pessa hina mikillato mey sva at petta var fregit vm allt brettlan $n$ d er liggr i frannz konungs riki. firir svnnan englandz sio" (Cook and Tveitane 1979, I50) ["The news of this proud maiden became so widely known that it was heard throughout Brittany, which lies in the realm of the French king, to the south of the English Channel" (Cook and Tveitane 1979, I5I)]. Adding details such as the location of Brittany with respect to the English Channel, the Norse text offers its readers a clear picture of the locations in question and the relationships between them. This is not to imply that a thirteenth-century Norwegian audience knew nothing about Britain; the close trade and political relationships noted above suggests that this would be unlikely, at least on the part of some members of the target audience. Rather, the addition of these details may be read as an attempt to write Britain into the mental geography of romance and lai. Such details help to establish Britain as a romance space-a literary rather than a real-world entity - for a Norwegian audience still relatively unfamiliar with the matiere de Bretagne and related texts.

These added geographical details contribute to the tension noted earlier: seen from without, Britain is fixed in geographical space. Seen from within, it is deceptive and confusing. In Doun, the broad expanse of the island of Britain appears to function as a challenge for the proud lady's suitors, but it is no more than a decoy. When those suitors who successfully complete the lady's challenge arrive in Edinburgh, they are worn out from their long journey. Their weakened state allows the lady to smother them with the heavy bedclothes she leaves in their rooms. Marianne Kalinke has discussed the trope of the maiden-king who shames or mutilates prospective suitors as they sleep (I990, 76-8); here, too, the text plays on the ironic reversal of the pleasure the suitors expect to find in the marriage bed as the woman asserts control over both her land and her body. Doun alone sees through the deception, survives the night, and in the morning, demands that the lady marry him. However, the lady is unwilling to give up her independence, and 
the text then follows a pattern found repeatedly in the Strengleikar lais, and particularly in those lais set in Britain: the hero must embark upon a second journey through the landscape, one which mirrors, and yet further complicates, the journey already accomplished.

In this case, the second journey parallels the first, as the lady demands that Doun ride his horse as far as her swan can fly. The geographical specificity that distinguished the first challenge is entirely lacking in the second. Rather, this is a journey that is mapped in terms of a bird's flight; the length and destination of the journey are impossible to predict. There is also a supernatural quality to it: the French text calls it a "merveille" (Burgess and Brook 2007, v. I46) ["wonder" (Burgess and Brook 2007, 267) ], and the Norse text calls it an "unndr" (Cook and Tveitane 1979, I52) ["wonder" (Cook and Tveitane I979, I53)], that Doun and his horse are able to keep up with the swan. ${ }^{10}$ In both cases, the geographical expanse of Britain is held up as a challenge to conquer, and yet it is a decoy; the real trick is to survive the night that follows. In this lai, the doubling of the journey serves to emphasize the worthiness of the hero and his ability to bring peace and stability to a land that had initially threatened his well-being. As Jeff Rider has observed, romance "other worlds"-whether distanced from the protagonist's homeland by history, geography, or an element of the supernatural- "disrupt the order of a peaceful, stable aristocratic world. . . . Otherworldly intervention is not a threat to be countered but a catalyst that helps the central aristocratic society attain a new order by provoking a process through which a problem in that world is resolved or a fault in it is exposed" (2000, II8). In Doun, the lady's realm operates as an "otherworld" in which female autonomy prevails; however, Doun's successful navigation of that world allows him to marry the female ruler and so to bring her land back within the sphere of male control.

Having abandoned his pregnant wife four days after their wedding, Doun assumes complete lordship over both land and lady at the end of the lai:

Siðan foro peir með hestu $m$ sinu $m$ yuir ænglandz sio. ok fóerðe pa $\operatorname{svein} n \operatorname{in} n$ faður $\sin n$ til moðvr $\sin n$ ar. er lengi hafðe til langat

IO. The rivalry between the two animals stands in marked contrast to the actions of the swan in Milun: in that lai, the animal provides a secret mode of communication between the protagonist and his lover. With its Welsh setting and the final contest between father and son, Milun is otherwise a close analogue to Doun (see Burgess and Brook 2007, 247-50). 
heimkvamo hans. ho〈n〉 tóc við honum i miclu $m$ fagnaðe sem eignu $m$ spusa sinv $m$ ok herra. Siða $n$ lifðo pau i miclum friðe ok fagnaðe marga vetr | sampyckilega ok sœmilega. (Cook and Tveitane I979, I56)

Then they travelled with their horses across the English Channel, and the boy led his father to his mother, who had long been waiting anxiously for his return. She received him joyfully as her own husband and lord. Then they lived in great peace and pleasure for many years, harmoniously and honorably. (Cook and Tveitane 1979, I57)

Led by his son, Doun's final journey across Britain is short and uneventful; it is untroubled by the deceptions and challenges that accompanied the winning of the lady. The land is tamed, as is its ruler. The successful negotiation of the land parallels Doun's forced socialization of the haughty woman who has learned to conform to the more appropriate roles of wife and mother. In this way, the lai of Doun leads its readers through an examination of the boundaries of gender and power in the romance genre and, perhaps, in courtly society more generally.

\section{DESIRE}

The lai of Desire follows the plot of the more famous tale of Janual, translated from Marie's lai de Lanval. ${ }^{11}$ It is the story of a hero who finds a fairy lover in the forest but loses her through the breaking of a prohibition; eventually the hero wins her back and both disappear to the fairy otherworld. As in Doun, the Norse text elaborates on the French in its description of Britain and of the island's location with respect to mainland Europe. When the hero's mother wishes to go to France to pray for a child, the French text notes simply that she plans to travel to the shrine of St. Giles, "en Provence, dela la mer" (Burgess and Brook 2007, v. 28) ["in Provence, beyond the sea" (Burgess and Brook 2007, 43)]; the Norse text expands this to, "fyrir sunnan xnglandz sió i provenz fylki" (Cook and Tveitane 1979, IO8) ["to the south of the English Channel, in Provence" (Cook and Tveitane 1979, I09)]. Similarly, the French text repeats the phrase "passer la mer" (to cross the sea) three times as characters move between Britain

II. For a study of the relationship between the Anglo-Norman lais Desiré, Graelent, and Lanval, see Margaret Grimes (1976, I2-13). Sif Rikhardsdottir discusses the relationship between the Old Norse Januals ljó 0 and its analogues in Anglo-Norman and Middle English (2OI2, 38-45). Burgess and Brook give a detailed comparison of the two manuscript versions of the French lai, as well as an overview of the principle analogues and themes (2007, II-79). All citations are from this edition. 
and the Continent (Burgess and Brook 2007, vv. 38, 4I, 70); in such cases, the Norse text substitutes the phrase englandz sio (the English Channel) for the more general la mer (Cook and Tveitane 1979, IO8IO). ${ }^{12}$ The geographical perspective of the writers also seems to have influenced their choice of language in the two tales. The French text locates Desiré's birthplace in faraway Scotland, "Encoste de la Blanche Lande / Outre la mer qui tant est grande" (Burgess and Brook 2007, vv. 9-IO) ["Near the Blanche Lande, / Beyond the broad expanse of ocean" (Burgess and Brook 2007, 43)], where his father is a vassal of the Scottish king. In the Norse version, by contrast, Desiré's father is a vassal of the French king and his Scottish homeland is "nér par sem hæitir huitiskógr. hia havi hinu mykla. er uttan at gengr" (Cook and Tveitane I979, I08) ["near the place called White Forest, next to where the great sea comes in" (Cook and Tveitane I979, I09)]. The feudal relationship between France and Scotland, as well as the sea that flows útan, from one geographical region to another, emphasizes not the distance between the countries but their relationship with each other. Such changes are minor when compared to the more sustained process of elaboration in Doun, but they have the same effect of giving the reader a detailed mental map of the island of Britain with respect to its Continental neighbors.

The real focus in Desire is on the hero's journey within the island of Britain itself. Desiré goes to France as a young man in order to prove himself as a knight; when he returns to his home in Scotland seven years later, he is well practiced in the art of war. He is, though, in need of mental and emotional training to become truly knightly. A series of journeys within Britain effect this education and emphasize far more strongly than Doun the potential of the romance landscape to instill courtly values in those who travel through it. Desiré's first journey occurs as he rides in search of an old friend, a hermit. However, the landscape seems to transform as he rides, and the Norse text evokes the uncanny, hallucinatory nature of that experience:

studdizc hann i istigu $m$ sinu $m$ ok laust han $n$ með sporu $m$ hæstin $n$. ok lœypti hann hæstino $m$ uændilega dala. ok for hann með pesso $m$ hætti xin $n$ saman. on felaga ok stæfnde pangat $\operatorname{sem} \operatorname{men} n$ kalla huitaskogen $n$.

I2. Such elaboration may be a rather prosaic reflection of what the Norwegian audience was assumed to know about the geography of France and England; however, it also speaks to Eldar Heide's observations on the importance of crossing water to access holy islands and other forms of otherworlds in medieval Scandinavia and beyond (2OII). 
ok sa hann par marga fagra viði. með laufom ok blomum. ok hævir hann hœyrt fugla syngia sua fagre roddu. at hann lysti til at lyða. snys hugr hans allr. ok hiarta. ok allr pottezc han $n$ a lofte vera. Siðan ræið hann fram $m$ i morkena. (Cook and Tveitane I979, II2)

He raised himself up in his stirrups and pricked the horse with his spurs, galloping it through endless valleys, and he went on alone in this way, without companions, and headed toward the place called "White Forest". There he saw many beautiful trees with leaves and blossoms, and he heard the birds sing in such fair voices that he listened eagerly. His whole mind and mood got turned around, and he felt he was floating on air. Then he rode on into the forest. (Cook and Tveitane I979, II3)

The Norse translator expands on the French text to describe fully the bewildering environment through which Desiré moves. His ride through uandilega dala (endless valleys) replaces a more prosaic statement in the French that he rode "tote la vile contreval" (Burgess and Brook 2007, v. II6) ["down through the town" (47)]. Such a description seems to be focalized through Desiré himself, reflecting his impression of the land around him rather than his exact route. In French, the emotional effect of the journey is expressed through Desiré's bodily reaction: "Li sans li remue et tressaut, / Le corage li monte en haut" (vv. I2I-2) ["His blood stirred and started, / And his heart leapt" (47)]. In contrast, the Norse text casts his reaction as more cerebral and impressionistic, as both his heart and mind whirl within him. The use of the verb pykkja (to seem) is absent in the French, as is the sensation of floating through air. These changes in the Norse text emphasize the protagonist's perception of what is happening, rather than what actually happens. Although Desiré thinks he is following the path he has always taken in order to visit the hermit, he arrives in the fairy-like hideaway of a mysterious lady, who soon becomes his lover.

This substitution of a lady's bower for the hermit's chapel marks the beginning of Desiré's education as an adult knight. A voluptuous lady is substituted for a confessor, love for religion. However, the lady does not allow Desiré to remain in the forest forever. She demands that he balance his obligations to the court with his love for her: "engvm riddara samir at fyrirlata frægð sina sacar kvenna asta" (Cook and Tveitane I979, II6) ["It is not right that any knight should give up his reputation for the love of women" (Coot and Tveitane I979, II7)]. As Glyn Burgess and Leslie Brook observe, Chrétien de Troyes includes similar comments in his Yvain and Evec et Enide: a true knight, it seems, 
must not allow love to interfere with other chivalric pursuits (2007, 22). Desiré accepts the wisdom of this lesson, but fails in the greater challenge of reconciling his Christian faith with his relationship with the fairy. Desiré makes the mistake of seeing physical love and spiritual love as mutually exclusive, and, in a burst of contrition, confesses his affair to the hermit. The lady abandons him for one year; when she reappears, she berates him for this act and argues that there is nothing sinful about their affair because neither is married. Declaring that she is not an "ilska vetr" (Cook and Tveitane I979, I20) ["evil creature" (Cook and Tveitane I979, I2I)], she takes communion with him in church. In so doing, the lady rejects the strict division that Desiré perceives between the world of the court and that of the forest. It is notable that, as Desiré begins to understand his error, the language of religion seeps into his address to the fairy: "Nu bið ec pic at pu miskunnir pvi er ec hevi misgort . . legg slica skrift a mik sem pv villt" (Cook and Tveitane I979, II8) ["Now I beg you to have mercy for what I have done wrong. . . . Assign to me whatever penance you please" (Cook and Tveitane I979, II9)]. Such language emphasizes the blurring between physical love and spiritual love in Desiré's mind. Noting the pun on Desiré's name, Jaques de Caluwé has argued that this encounter exemplifies "la concrétisation d'un éternel désir" [the concretization of an eternal desire] in the construction of the fairy otherworld: "Désir de s'abandonner et de trouver chez l'autre le plaisir sans péché et la transcendance sans ennui, désir d'entendre chez le même être, enfin en harmonie, les soupirs de la sainte et les cris de la fée" (de Caluwé I983, 65) [ the desire to let oneself go and to find with another pleasure without sin and transcendence without tedium, the desire to hear in the same being, at last in harmony, the sighs of the saint and the cries of the fairy]. Perhaps surprisingly, it is a mysterious woman from the fairy otherworld who teaches Desiré to balance his roles as lover, knight, and Christian. Although the path through the White Forest leads at times to the hermit, at times to the fairy, the lai demonstrates that these apparently different destinations are in fact intertwined: love, religion, and chivalry are all essential aspects of ideal knighthood in the world of romance. As Desiré learns to negotiate the ever-changing path through the forest, he also comes to understand the different but complementary facets of courtly behavior and identity.

As it is in Doun, however, so it is in Desire: the journey into the forest is repeated, and a further test presented to the hero. In a second adventure that takes place some years later, Desiré is hunting in the 
forest with the king of Scotland when they find a stag. As the Norse text relates:

konungrenn ok desire namo / baðer staðar vn $n$ dir einu $m$ miclvm viði. ok skutu peir baðer i sen $n$ at einu $m$ hirti. ok gato peir hvarki sárt hann ne drepit. ok komo niðr skeyti peirra skamt ifrá peim i grasvollin $n$. sva at baðir peir sa. ok pottozc peir baðer suivirðir ok spottaðer at hiortrin $n$ komzc usar $r$ v $n$ ndan peim. ok castaðo peir pa bogu $m$ sinu $m$ ok toco af benzlvm. ok toco ${ }^{13}$ orvar sinar par sem pær varo niðr fallnar pa mællti desire. at visu ero petta kvað han $n$ sionhverfingar at við fin $n v m$ ei orvar ocrar er nu beint her niðr fello i augliti beggia occarra. at visu samir ocr unndra pat er við siom ok uitum sva kynlect vera. (Cook and Tveitane 1979, I22)

The king and Desiré stopped under a large tree and they both shot at the same time at a stag, but they could neither wound it nor kill it, and their arrows fell down on the grass a short distance from them-as they saw it. They felt deceived and mocked that the stag escaped them untouched. They threw away their bows and unbent them and wanted to pick up their arrows where they had fallen down. Then Desiré spoke: "It is surely," he said, "an optical illusion that we cannot find our arrows, which fell down right here in sight of us both. Surely we ought to marvel at what we see and know to be so strange." (Cook and Tveitane 1979, I23)

This episode is adapted almost exactly from the French, but with the important difference that in the source text, it is the king who speaks to Desiré. The reversal of who is speaking to whom in the Norse version shifts the focus onto how Desiré perceives the mysterious world around him, and how his experience in that world molds his character. The emphasis on sight and mis-seeing is very strong in the Norse text. In Strengleikar, Desiré assumes that he cannot see the arrows because of some sort of sjónhverfing, or optical illusion. However, in the French text, the king simply assumes that he and his companion have been enchanted: "Nos somes tuit enfantosmé" (Burgess and Brook 2007, v. 482) ["We have all been bewitched" (Burgess and Brook 2007, 63)], he exclaims. Writing of the marvelous signs that appear when romance characters travel to strange or supernatural places, Rider observes that such signs appear marvelous only to the characters who encounter them. In contrast, the experienced reader

I3. Cook and Tveitane follow previous editors, as well as the Anglo-Norman source text, in assuming that the second toco is a scribal error for sotto, and translate accordingly (I979, I23). 
of romance comes to realize that marvels are part of the conventions that govern that genre: "One cannot, that is, really marvel at fictive marvels, even though one recognizes that one would marvel at them if one really encountered them in life. A fictive marvel is, rather, a kind of enigma that makes a reader ask, not 'what is its cause?' but 'what does it mean?" (Rider 2000, I2I). Like any good reader of romance, Desiré wants to know not what causes the illusion, but what it means. Desiré is becoming increasingly aware of the trickery the forest can play. Unlike the king in the French text, he does not leap to conclusions immediately, and it is notable that this moment of optical trickery also ushers in a moment of revelation. A young man appears, carrying the lost arrows, and tells Desiré that he is his son. In contrast to the illusion of the arrows, the boy brings with him the ring that his fairy mother once gave to Desiré as a sign of their love; the knight recognizes it and so gains a son. This episode is about learning to read mysterious signs correctly. Desiré correctly interprets the disappearing arrows as an optical illusion, and he correctly identifies the ring the boy carries. As with the two pathways through the forest, he is here faced with two signs to interpret. However, unlike the previous episode, he accurately interprets both signs. Desiré is slowly gaining the skills to "read" the confusing romance world around him.

Desiré's final challenge in the deceptive British landscape occurs when his son suddenly rides off into the forest. Declaring that he would rather die than lose the boy, Desiré gallops after him. However, in an uncharacteristic moment of physical comedy, he rides straight into a tree: “ok nauð hofði sino mioc fast sva at hann fell opinn aftr. . . . Nu misti hann sveinsens ok vissi hann ei hvert hann stefndi" (Cook and Tveitane I979, I24-6) ["and he hit his head so hard that he fell flat on his back. . . . Now he had lost the boy and did not know where he was headed" (Cook and Tveitane I979, I25-7)]. This ignominious tumble from the horse highlights the futility of Desiré's actions; when he rides after the boy, he acts from the heart rather than the head, and he is punished for it. Wandering dazed through the forest, Desiré is for a third time presented with a strange creature, a dwarf, who again teaches him the importance of interpreting signs correctly. Just as he allows his love for his son to lead him straight into a tree, his impetuous desire to reunite with his lover blinds him to the potential dishonesty of the dwarf. ${ }^{14}$ In the French text, Desiré's exemplary table manners

I4. For a comprehensive discussion of the role of dwarves in romance and in the Anglo-Norman version of this lai, see Anne Martineau (2003, esp. 56-7). 
prompt the dwarf to offer to lead Desiré to his mistress's bedroom. The Norse translator expands upon this invitation as the dwarf declares: "po at ec se barðr sacar pin. vil ec ei lengr hallda pogn firir pér né leynazc firir pér . . . ei vil ec leyna pic lengr. unnasta pin sende mic hengat" (Cook and Tveitane 1979, I26-8) ["Even though I might be beaten on your account, I will no longer maintain silence with you or hide from you ... I will conceal it from you no longer: your sweetheart sent me here" (I27-9)]. Negative phrases such as ei hallda pogn (not to maintain silence) and ei leyna (not to conceal) ironically raise the possibility of deception even as the dwarf protests his sincerity. He further proves his credentials by serving Desiré dinner on golden bowls that the knight knows belong to the lady. Like the ring offered by the son to his father, the golden bowls are signs of the lady's mysterious world, and Desiré recognizes them as such. However, while the boy's gold ring functions as a sign of recognition, here, the golden bowls only lend credence to the deception. Desiré's impetuous desire to see his beloved blinds him to the possibility of trickery. It is therefore no surprise that Desiré's attempt to see his lady is unsuccessful: when he leaps through the window of her bedroom, he is thrown off balance and severely wounded. In this episode, the two falls—one off the horse and one through the window-result in two wounds, as well as two embarrassing failures. The repeated punishment of his body acts as an unequivocal signal that Desiré has chosen wrongly, that he has failed to read accurately the signs of the romance world. In this case, both his rashness and his willingness to listen to emotion have led him astray.

It is an effective lesson in the dangers of uncontrolled emotion, and this episode marks the end of his education in the lai. The story concludes in the same manner as its analogues: the lady appears publicly at the king's court to proclaim her relationship with Desiré; she asks the king to dub their son a knight and to provide for their daughter. Afterward, she and Desiré ride away to the fairy otherworld. Desiré's final departure is the logical conclusion of the many journeys he has attempted throughout the course of the lai. Each journey has in some way been bewildering, deceptive, or humiliating. And yet, through the course of these journeys, both Desiré and the reader have learned something about what it takes to be a knight. Rather paradoxically, his final departure from the world of the court breaks the circularity of this pattern and indicates that his education as a knight is complete. As the lady declares in the closing lines of the story, "hofo vit lokit goðre syslo" (Cook and Tveitane 1979, I32) ["We have had good success" (I33)]. 


\section{Glossing The TeXT}

Doun and Desire demonstrate well the apparently contradictory depictions of the island of Britain found within the Strengleikar collection: seen from without, Britain's geography is clear and fixed; seen from within, the land is deceptive, and the romance protagonists must learn to negotiate it correctly through repeated journeying. Although there is not space here to discuss them fully, a number of the Strengleikar texts exhibit similar tendencies. The lai of Jonet, for example, describes the journeys of a woman who travels through a strange, dreamlike landscape in Cornwall, first alone and then many years later with her son. The pattern appears again in the lai of Gurun, set in Scotland, which combines the journey motif with battle and with a game of wits played between the hero and his sweetheart's dwarf-guardian. Such journeys may be seen as a process of decoding in which the romance protagonists learn to read and re-read the landscape, and to interpret correctly its meaning. The reader, too, is led through the text on a parallel intellectual journey. As Marie de France notes in her introduction to the Lais, obscurity pushes a reader to decode and interact with the challenges of the obliquely written text. The Old Norse rendering of her comments in the prologue to Strengleikar reads as follows: ${ }^{15}$

Pa var siðr hyggin $n$ a ok hœverskra manna i fyrnskon $n$ e at pæir mællto froðe sin sua sem segi með myrkom orðom. ok duipo $m$ skilnengo $m$. saker pæirra se $m$ ukomner varo. at pæir skylldo lysa með lioso $m$ umrœðo $m$ pat se $m$ hin ir fyrro hofðo mællt. ok ran $n z$ aka af sinu viti pat se $m$ til skyringar horfðe ok rettrar skilnengar. af pæi $m$ kæn $n$ nngom er philosophi forner spekingar hofðu gort. (Cook and Tveitane 1979, 6)

It was the custom of wise and well-mannered men in olden days that they should set forth their learning, so to speak, in dark words and deep meanings for the sake of those who had not yet come, that these should explicate in lucid discourse that which their forbears had said and probe with their intelligence whatever pertained to the elucidation and correct understanding of the teachings which philosophers, sages of long ago, had made. (Cook and Tveitane 1979, 7)

I5. The Anglo-Norman text reads: "Custume fu as anciëns, / Ceo testimoine Preciëns, / Es livres ke jadis feseient, / Assez oscurement diseient / Pur ceus ki a venir esteient / E ki aprendre les deveient, / K'i peüssent gloser la lettre / E de lur sen le surplus mettre" (Rychner 1983, vv. 9-16) [It was the custom of the ancient writers, as Priscian attests, long ago to write books in which they expressed themselves obscurely, so that those who came afterward and who needed to learn from them could gloss the text and add to their meaning]. 
The play in both texts between obscurity and clarity, darkness and light, speaks directly to the process of exploration and elucidation that heroes such as Doun and Desiré undergo. The travel of these knights through the landscape of Britain is a process analogous to reading the text itself: the knights journey again and again over the same road, and as they do so, they learn to negotiate its deceptions, its obscurity. Similarly, the reader must read and reread the written text in order to illuminate its meaning. For this reason, the knights' ability to decode the confusing landscape of Britain should be seen as a model for readers at the court of King Hákon as they are led through the process of learning to "gloss" the romance genre. Lais such as Doun and Desire demonstrate the surprisingly complex role played by the British landscape in the Strengleikar collection. Just as the Cornish wood furnished Tristan with the multilayered message of the hazel branch in Geitarlauf, so the British landscape becomes both a site in which to explore the conventions of romance and a metaphor for the reading process itself in Doun and Desire.

\section{WORKs Cited}

Burgess, Glyn S., and Leslie C. Brook, eds. 2007. French Arthurian Literature. IV: Eleven Old French Narrative Lays. Arthurian Archives Vol. XIV. Cambridge, England: D. S. Brewer.

Carruthers, Mary. 1998. The Craft of Thought: Meditation, Rhetoric, and the Making of Images, 400-I200. Cambridge Studies in Medieval Literature. Cambridge, England: Cambridge University Press.

- 20IO. "The Concept of ductus, or Journeying through a Work of Art." In Rhetoric beyond Words: Delight and Persuasion in the Arts of the Middle Ages, edited by Mary Carruthers, 190-213. Cambridge Studies in Medieval Literature. Cambridge, England: Cambridge University Press.

Cook, Robert, and Mattias Tveitane, eds. and trans. 1979. Strengleikar: An Old Norse Translation of Twenty-One Old French Lais. Norrøne tekster 3. Oslo: Norsk historisk kjeldeskrift-institutt.

de Caluwé, Jacques. 1983. "L'Autre Monde celtique et l'élément chrétien dans les lais anonymes." In The Legend of Arthur in the Middle Ages: Studies Presented to A. H. Diverres by Colleagues, Pupils, and Friends, edited by P. B. Grout, R. A. Lodge, C. E. Pickford, and E. K. C. Varty, 56-66. Arthurian Studies VII. Cambridge, England: D. S. Brewer.

Eriksen, Stefka Georgieva. 2007. "Popular Culture and Royal Propaganda in Norway and Iceland in the 13th Century." Collegium Medievale 20: 99-I35.

Grimes, E. Margaret, ed. 1976. The Lays of Desiré, Graelent and Melion: Edition of the Texts with an Introduction. Geneva: Slatkine.

Haidu, Peter. 2004. The Subject Medieval/Modern: Text and Governance in the Middle Ages. Stanford, CA: Stanford University Press. 
Heide, Eldar. 20II. "Holy Islands and the Otherworld: Places beyond Water." In Isolated Islands in Medieval Nature, Culture and Mind, edited by Gerhard Jaritz and Torstein Jørgensen, 57-80. CEU Medievalia I4. Muhu Procedings 2. Budapest: Central European University, Centre for Medieval Studies, University of Bergen.

Helle, Knut. 1968. "Anglo-Norwegian Relations in the Reign of Håkon Håkonsson (I2I7-63)." Mediaeval Scandinavia I: IOI-I4.

Jaeger, C. Stephen. 1985. The Origins of Courtliness: Civilizing Trends and the Formation of Courtly Ideals 939-I210. Philadelphia: University of Pennsylvania Press.

Jorgensen, Peter, ed. and trans. 1999. Tristrams saga ok Isöndar. In Norse Romance. Vol. I: The Tristan Legend, edited by Marianne E. Kalinke, 23-226. Arthurian Archives III. Cambridge, England: D. S. Brewer.

Kalinke, Marianne. 1990. Bridal-Quest Romance in Medieval Iceland. Islandica 46. Ithaca, NY: Cornell University Press.

- ed. 20II. The Arthur of the North: The Arthurian Legend in the Norse and Rus' Realms. Arthurian Literature in the Middle Ages V. Cardiff: University of Wales Press.

Larrington, Carolyne. 2008. "The Enchantress, the Knight and the Cleric: Authorial Surrogates in Arthurian Romance." Arthurian Literature 25: 43-65.

- 2009. "Queens and Bodies: The Norwegian Translated lais and Hákon IV's Kinswomen." Journal of English and Germanic Philology IO8 (4): 506-27.

Leach, Henry Goddard. I92I. Angevin Britain and Scandinavia. Cambridge, MA: Harvard University Press.

Loomis, Roger Sherman. 1949. Arthurian Tradition and Chrétien de Troyes. New York: Columbia University Press.

Lozac'hmeur, Jean-Claude. 1984. “D’Yvain à Désiré: Recherches sur les origines de la légende d'Yvain." Études celtiques 21: 257-63.

Martineau, Anne. 2003. Le Nain et le chevalier: Essai sur les nains français du Moyen Age. Paris: Presses de l'Université de Paris-Sorbonne.

Meissner, Rudolf. 1902. Die Strengleikar: Ein Beitrag zur Geschiche der altnordischen Prosalitteratur. Halle a. S.: Max Niemeyer.

Putter, Ad. 1995. Sir Gawain and the Green Knight and French Arthurian Romance. Oxford, England: Clarendon.

Rider, Jeff. 2000. "The Other Worlds of Romance." In The Cambridge Companion to Medieval Romance, edited by Roberta Krueger, II5-3I. Cambridge, England: Cambridge University Press.

Rouse, Robert Allen, and Cory James Rushton. 2009. "Arthurian Geography." In The Cambridge Companion to the Arthurian Legend, edited by Elizabeth Archibald and Ad Putter, 2I8-34. Cambridge, England: Cambridge University Press.

Rychner, Jean, ed. 1983. Les Lais de Marie de France. Les classiques français du moyen age. Paris: Éditions Champion.

Schach, Paul. 1975. "Some Observations on the Translations of Brother Róbert." In Les Relations littéraires Franco-Scandinaves au Moyen Age: Actes du Colloque de Liège, avril 1972. Bibliothèque de la Faculté de philosophie et lettres de l'Université de Liège 208, II7-35. Paris: Société d'Édition "Les Belles Lettres."

Sif Rikhardsdottir, 20I2. Medieval Translations and Cultural Discourse: The Movement of Texts in England, France, and Scandinavia. Cambridge, England: D. S. Brewer.

Tveitane, Mattias, ed. 1972. Elis saga, Strengleikar and Other Texts: Uppsala University Library, Delagardieska samlingen nos.4 7 folio and AM $666 b$ quarto. Corpus 
codicum norvegicorum medii aevi, quarto serie 4. Oslo: Selskapet til utgivelse av gamle norske håndskrifter.

Warren, Michelle R. 2000. History on the Edge: Excalibur and the Borders of Britain, II00-I300. Medieval Cultures 22. Minneapolis: University of Minnesota Press.

Wiesmann-Wiedemann, Friederike. 1978. "Glose to the sen of Marie de France's Chievrefoil." In Fifteenth-Century Studies. Vol. I, edited by Guy R. Mermier and Edelgard E. DuBruck, 287-313. Ann Arbor: Medieval Institute, Western Michigan University. 